\title{
Biblical Allusions, Antithetical Structures and Triads: A Stylistics-Rhetoric Appraisal of Some Speeches by Martin Luther King Junior
}

\author{
Seino Evangeline Agwa Fomukong ${ }^{1}$ \\ ${ }^{1}$ Department of English Modern Letters, Higher Teacher Training College, University of Bamenda, North West \\ Region, Cameroon \\ Correspondence: Seino Evangeline Agwa Fomukong, Department of English Modern Letters, Higher Teacher \\ Training College, P.O. Box 39 Bambili, University of Bamenda, North West Region, Cameroon. E-mail: \\ seinoeva2014@yahoo.com
}

$\begin{array}{ll}\text { Received: September 29, } 2015 & \text { Accepted: October 26, } 2015 \text { Online Published: November 30, } 2015 \\ \text { doi:10.5539/ijel.v5n6p11 } & \text { URL: http://dx.doi.org/10.5539/ijel.v5n6p11 }\end{array}$

\begin{abstract}
In a text, linguistic choices are made by the language user depending on the linguistic resources available to them. The language user relies on appropriate and embellished use of language to make their work interesting and produce a special effect on their audience. For this effect to take place there is an interplay of the linguistic and situational aspects of language. Stylistic analysis therefore aims at explicating how the understanding of a text is achieved, by examining in detail the linguistic organization of a text in relation to the context of situation, and focussing on the affective content. This can be linked to the study of rhetoric which is all about a set of rules and strategies which enable orators to speak well, using language in a more decorative and embellished manner to affect the opinions and feelings of the audience. This is persuasive language, which makes the audience not just to respond emotionally but to identify with the writer's point of view, to feel what the writer feels. It is against this background that this study is going to carry out a stylistic rhetoric analysis on the language used by Martin Luther King Junior in six of his speeches. In these speeches he uses biblical allusions, antithetical structures and triads emphatically, as stylistic devices that make his speeches more memorable and appeal to the emotions of his audience.
\end{abstract}

Keywords: Biblical allusions, antithesis, triads, stylistics, rhetoric, Halliday's metafunctions of language

\section{Introduction}

In a text, linguistic choices are made by the language user depending on the linguistic resources available to them. These choices are determined by what Halliday calls the 'field' and also by other social and contextual variables. Yeibo (2011) highlights Wellek and Waren (1977, p. 22) who argue that language is a material to literature as stone or bronze is of sculpture, paints of picture, or sounds of music. In using language therefore the user uses beautiful language to encode meaning in a text, whether literary or non-literary. This beautiful language is like bronze, paint or sounds. The language user relies on appropriate and embellished use of language to make their work interesting to their audience; this determines the user's style. That is the linguistic choices made reveal the writer's personality and is carefully chosen to produce a specific effect on the audience.

Stylistics examines the reasons for certain language choices in a text and explores how readers interact with the language of a text in order to explain how they understand a text and how they are being affected by the text. In the interpretation of a text Hymes in Sinclair and Coulthard (1978, pp. 38-39) gives a check list of features of context which may be relevant to identify a communicative event and thereby understanding a text. These features are addressor, addressee, audience, topic, setting, channel, code, message-form, event, key and purpose. This is in line with Halliday and Hasan $(1985$, p. 20) who argue that there are two different kinds of considerations in language, not only the linguistic clues but also the situational ones. The linguistic concerns relations within the language, patterns of meaning realised by grammar and vocabulary, and the other, situational, concerns the relations between the language and the features of the speaker's and hearer's material, social and ideological environment. This implies that the linguistic patterns also make possible to identify what features of the environment are relevant to linguistic behaviour and so form part of the context of situation. The intention of 
the writer therefore connects the chosen diction and syntactic expressions to the activities taking place in the writer's environment. Halliday and Hasan $(1985$, p. 21) go on to posit that the 'context of situation' in which a text is embedded, refers to all those extra-linguistic factors which have some bearing on the text itself. This brings into play the relationship that exists between Halliday's 'context of situation' which include: field, mode and tenor, and metafunction of language, made up of the ideational, interpersonal and the textual functions. These language functions link the event, the participants and the medium used to pass across the message making the choice of language dependent on these aspects.

Stylistic analysis therefore aims at explicating how the understanding of a text is achieved, by examining in detail the linguistic organization of a text. The analysis of the text also examines in great detail, identifying linguistic patterns relating them to the function they perform in a given context. This stylistic analysis is sometimes narrowed to focus on more striking features of language. The reason behind studying these linguistic features is to decode the meaning of the texts. Khattak et al. (2012) quote Person (2001), saying that the goal of stylistics is not only to describe the formal features of texts for their own sake, but in order to show their functional significance for the interpretation of the text. These features are used by the writers to appeal to the emotions of the readers.

Taylor (1980, p. 25) states that stylistics studies the elements of a language organised from the point of view of their affective content; that is the expression of emotion by language as well as the effect of language on the emotions. This can be linked to the study of rhetoric which is about a set of rules and strategies which enable orators to speak well, using language in a more decorative and embellished manner to affect the opinions and feelings of the audience. This is persuasive language, meant to impress or affect listeners or readers, emotionally.

This persuasive language has three modes of persuasion as given by Aristotle in Plato.stanford,edu. The modes of persuasion, often referred to as rhetorical strategies or rhetorical appeals, are devices in rhetoric that classify the speaker's appeal to the audience. These modes of persuasion are ethos (character of the speaker), pathos (emotional influence of the on the audience) and logos (content and argument). The focus here is on pathos. Pathos, when applied to speech stirs up the emotions of the audience. As Wikipedia puts it, "pathos may also include appeals to imagination and hopes; done when the speaker paints a scenario of positive future results of following the course of action proposed'. Pathos thus refers to the emotional impact of the author's message on an audience, the power with which the writer's message moves the audience to decision or action. It causes an audience not just to respond emotionally but to identify with the writer's point of view and to feel what the writer feels. It is against this background that this study is going to carry out a stylistics rhetoric analysis on the language used by Martin Luther King Junior in six of his speeches, taking into cognizance the trilling devices he uses to stir up pathos in his audience. These devices are Biblical allusions, antithetical structures and triads.

\section{Rationale of the Study}

Martin Luther King Junior., a black American, was born in 1929 into a Christian home. With his father as a Christian he was committed to the Bible as a primary source of inspiration to fight racial injustice. It is these bible stories that sustained him and one of the reasons for his remarkable and memorable speeches. These stories added flavour, persuasion and meaning to his speeches as a pastor-civil rights activist. Lull (2011) states 'it was the Bible that led him to choose the more excellent way of love and nonviolent protest over hatred, despair and violence'. Using biblical examples is a way of making his listeners understand that those who seek peace even in the midst of trials, temptations and tribulations, will receive God's help.

Even though his springboard was the Emancipation Proclamation, Martin Luther King Jr. draws much of linguistic diction from the Bible. His desire for freedom and liberty is expressed in his quote of Isaiah in I have a dream, 'that one day every valley shall be exalted, every hill and mountain shall be made low... and the glory of the Lord shall be revealed, and all flesh shall see it together.' The glory of the Lord will be revealed because all God's children will be considered the same. In this very speech he recapitulates the importance of the Declaration of Independence as a promissory note that had to lead all men to equal rights. The major themes in his speeches are love, nonviolence, equality and keeping the faith. He does these through the use of some stylistic devices: Biblical allusions, antithetical structures and triads.

Bringing together the experiences of blacks in America and the experience in the Bible is a way of inspiring the blacks to fight for their rights. He talks of 'the day when all God's children black men and white men, Jews and Gentiles will be able to live together' (Gal 3:28). Accordingly, both blacks and Whites are God's children. This implies unity in America, got without violence, creating spiritual unity in his audience. This unity is also shown in his plea for the protests to take place without violence. In his Letter from a Birmingham Jail Dr King is replying to clergymen who considered him as a civil rights activist, to be "unwise and untimely". He says he 
cannot sit idly and not be concerned about injustice in Birmingham. In his determination he draws inspiration from Shadrach, Meshach and Abednego in the Bible, who refused to obey Nebuchadnezzar's laws in Daniel 3:16-18. He advocates for nonviolent demonstration because as he professes, 'Jesus was an extremist for love'.

In his speeches MLKJ's demands for racial justice and an integrated society for the black community in America. In his fight for equality and racial justice between the blacks and the whites in America he captures his audience with speeches embellished with devices that help to contextualize his messages like the use of repetition to emphasize his message. These repetitions are of lexical, syntactic and semantic nature. His powerful and evocative speeches are ornamented with extended metaphor, metonymy, anaphora, parallelism and many other devices. This study is going to focus on biblical allusions, antithetical structures and triads, which help to express his ideas and persuaded the blacks to carry on with their quest for civil rights, racial justice and equality in all aspects of life. In all of his speeches he is clear in his support for a nonviolent demonstration as the best option and the only means for the blacks to succeed in their mission. He uses the image of love from the bible to convince them to 'love your enemies and considered the whites as brothers' and even says some of the whites support the course of the blacks.

It can be said that the whites were well placed in society, since there were some schools the white could attend and not blacks, some hotels and restaurants whites and not blacks could visit. This means the welfare of the blacks were neglected. The sought for equality can therefore be seen in the contrastive structures MLKJ uses in his speeches, for example, the 'quicksand of racial justice' as against the 'solid rock of brotherhood'. This use of contrast and metaphor convey the meaning that racial justice is like a quicksand- it is weak and bound to vanish. The brotherhood was like the solid rock that would stand firmly and last forever. This antithetical structure is to win the attention of audience, emphasize, educate and make the audience to desire freedom. An antithesis is when two ideas are put together in a sentence to achieve a contrasting effect. In this case an emphasis is laid on the idea of contrast by the parallel structures of the contrasted phrases or clauses, that is, the structures of phrases and clauses are similar in order to draw the attention of the listeners or readers and extract meaning. The combination of balanced structures with opposing ideas serve to emphasize the contrast between them. Antithesis has serious implications because it raises awareness and creates a vivid and memorable picture in the mind of the reader or listener. It also makes listening or reading enjoyable since there is pleasure in seeking for the hidden meanings out of a piece of work than it is when meaning is directly expressed.

The triad is a powerful device in speech making through which the speaker expresses their concepts completely and makes the speech memorable. According to Craigie (2013) it is a device of organising and presenting topics, words, phrases and ideas in groups of threes. Dlugan (2009) observes that, three is used for completeness, wholeness and roundness, and triad can be three successive words or three parallel elements. The triad or 'Rule of three' can be three successive words, phrases, sentences or even paragraphs. He gives examples of some famous occurrences. In Christianity, he talks of the three wise men with their gold, frankincense and myrrh; in films there is 'the good, the bad, and the ugly'; in literature he gives an example in Julius Caesar, 'I came, I saw, I conquered.' This study will be examining and analyzing the use triad, based on the metafunctions of language. According to Wikipedia the 'Rule of three' or the power of three is a writing principle that suggests that things that come in threes are inherently funnier, more satisfying, or more effective than the other numbers. This rule also makes information in a speech to be brief, rhythmic, simple, and catchy and to emphasize on an idea.

\section{Brief Look of the Speeches}

This study discusses six speeches of Martin Luther King Junior, randomly selected. The speeches to be discussed include: GIVE US THE BALLOT (May 1957), THE GREAT MARCH ON DETROIT (June 1963), I HAVE A DREAM (August 1963), WE SHALL OVERCOME (June 1966), BEYOND VIETNAM (April 1967), and WHERE DO WE GO FROM HERE (August 1967). It will examine the use of biblical allusions, antithetical structures and 'the rule of three' as pertinent strategies behind the captivating, convincing and persuasive speeches made by Martin Luther King Jr.

\subsection{Give Us the Ballots}

Give us the Ballots is a speech made at a prayer pilgrimage for a freedom nonviolent demonstration in Washington DC. This speech focuses on the demand for voting rights for Black Americans. MLKJ emphasizes that this rights is not only morally right but will lead to a better America because the blacks will not worry the Federal government about their basic rights, and also because their votes will write the law on statute books of the South, they will transform the salient misdeeds of bloodthirsty mobs into calculated good deeds of orderly citizens and they will implement the supreme court's decision of May seventeenth, 1954. He goes on to emphasize the need for a strong, moral and courageous leadership and calls on the blacks to be nonviolent, 
loving, and not to despair but hope for better days. He encourages them to keep moving 'amid obstacles and mountains of opposition' and ends his speech by telling them that if they will keep moving with dignity, history books will write, 'There lived a great people...a people who injected new meaning into the veins of civilization... a people that gave new integrity and new dimension of love to our civilization.'

\subsection{The Great March on Detroit}

The Great March on Detroit is a speech made by MLKJ in 1963. In this speech he makes the blacks to understand they have to fight for their rights because all men were created by God. He encourages them by telling them even if they are beaten and dragged into jail they should know their rights is a thing worth fighting and dying for. According to him, time is not on their side, since 'now is the time to lift our nation from the quicksand of racial injustice to the solid rock of racial justice.' He emphasizes nonviolence, love and togetherness and equally expresses his dreams by portraying America through the eyes of prophets like Isaiah and Amos in the Holy Bible. Like these prophets MLKJ sees a new found land where 'justice will roll down like waters and righteousness like a mighty stream, for every valley shall be exalted, and every hill and mountain shall be made low'. He makes the blacks to gain confidence in themselves and not to feel inferior because God created all men in his image and therefore all are significant before God. Towards the end of his speech he brings out his aspirations with the repetition of 'I have a dream...'. Before ending he presses on his listeners to have faith and believe they will achieve the dream of equality.

\subsection{Have a Dream}

In I Have a Dream, MLKJ calls for racial equality and an end to segregation. In this speech he inspires and informs the blacks about the difference between the blacks and the whites in America. He makes reference to the Emancipation Proclamation, which freed millions of slaves in 1863 , yet he observes that 100 years later the Negro is still not free. In his speech he likens the Declaration of Independence to a promissory note on which America has defaulted when it concerns the blacks and observes that 100 years after this declaration 'the negro lives on a lonely island of poverty in the midst of a vast ocean of material prosperity'. He makes so much use of repetition in the form of anaphora like 'One hundred years later, the negro..., so we have come..., Now is the time..., We must..., We can never be satisfied as long as..., Go back to..., I have a dream that one day..., with this faith..., Let freedom ring..., Free at last...' These repetitions instill in his audience believe that there will be a change.

\subsection{We Shall Overcome}

We shall overcome is a short but touching speech by MLKJ in 1966. The speech is against oppression in He assures his audience that 'we shall overcome' and repeats this throughout the speech. In this speech he instills in the blacks the desire to carry on with the fight for racial equality. He faces reality by telling them that before they win, 'some will be thrown in jail', 'some will have to face physical death', and 'some will be misunderstood and called bad names'. He ends with encouraging words for the blacks to keep on fighting because out of the 'dark chambers of pessimism will sprout new light' and leaves with the words 'walk together! Don't you get weary'.

\subsection{Beyond Vietnam: A Time to Break Silence}

In Beyond Vietnam: A Time to Break Silence (April 1967) MLKJ's is open and harsh against America's involvement in the war in Vietnam. He pleads with emotions 'I come to this platform tonight to make a passionate plea to my beloved nation.' He expresses his disappointment because of the hope that there was already an out led to his struggle against poverty in America, for blacks and whites alike. The Vietnam war shattered this hope, since much energy, men, skills and money was drawn to Vietnam. He sees the war as an enemy to the poor and likens the war to a 'demonic, destructive suction tube' and gives a vivid picture of Vietnamese women, children and the aged suffering, and also the picture of how American youths are killing and dying in Vietnam. He attributes to America the image of a person, by giving American a soul that dies and names the cause of the death when he laments 'if America's soul becomes totally poisoned, part of the autopsy must read "Vietnam"'. He concludes with a call for a revolution of values rather than war.

\subsection{Where Do We Go from Here}

Where Do We Go from Here is a speech delivered by MLKJ four months after Beyond Vietnam in 1967. In this speech MLKJ decries the maltreatment of the Negroes in America. He explains how blacks are barred from recreational activities, big city parks, and city libraries and denied access to the average lunch counter when they are hungry. He elaborates on the journey of struggling and tells them 'and so we still have a long, long way to go 
before we reach the promised land of freedom'. He focusses on togetherness and the need for the nation to restructure America and as usual encourages his audience to go in faith believing 'we would overcome'.

\section{Theoretical Framework}

This study uses as theoretical base, Halliday's metafunction of language. Halliday's theory of Metafunctions, dwells on three functional-semantic components which are ideational, interpersonal and textual functions. The ideational deals with the experience involved in language and the expression of 'content' with the function that language has of being about something (Halliday \& Hasan 1985). The ideational is subdivided into the experiential and the logical components. The experiential function refers to the language choices-grammatical choices made by the speakers that help to make meanings of the world around us. The logical functions are the systems that set up logical-semantic relationships between one clause and another. In this case a speaker chooses some meaning relation in bringing together two clauses. These clauses can be given the same status or one depending on the other.The interpersonal function enables the speakers to expose their relations. This takes into consideration the speaker and their audience. As Halliday and Hasan (1986) put it, this function is concerned with the social, expressive and conative functions of language with expressing the speaker's attitudes and judgments and his motives for saying anything.

The textual function turns the output of the ideational and the interpersonal and encompasses language as a system that creates a coherent text. Yeibo (2011) argues that the textual metafunction relates what is said in a text to ideas outside the discourse. The textual component therefore comprises the resources language has for creating a text, making it operationally relevant and cohering within itself and with the context of situation (Halliday \& Hasan1985). This implies arranging the message in a unified whole and making the message to fit logically with the wider context in which the event is taking place. The ideology of MLKJ is reflected through the linguistic choices he makes in his speeches.

Using as theoretical basis Halliday's functional-semantic components, this study is going to look at the way Martin Luther King organises, and embellishes his language so as to effectively put across his message. His religious background and experiences as a black in America gives him a rich stock of language to make his choice of language. The racial discrimination and social injustice at the time created an event for MLKJ to have a rapport with his audience. This event- the ideational component, creates an interaction with his audience- the interpersonal, and brings together in a coherent whole- the textual, to give the basis of Halliday's metafunction of language in this study. He takes into consideration his audience as he makes extensive use of stylistics rhetoric devices that make his speeches musical, emphatic and memorable. This will be analyzed in his speeches with focus on Biblical allusions, antithetical structures and the use of the 'rule of three, or triad. These linguistic choices made by MKLJ probe from real situation of the equality struggles of the blacks, MLKJ's Christian background and the effective use of language as a persuasive tool.

\section{Analysis and Findings}

The analysis of this study looks at the Biblical allusions, antithetical structures and triad as used by Martin Luther King Junior (MLKJ) in his speeches. These three aspects of language analysis are used in this study to decode meaning from MLKJ's speeches and interpret the speeches in context, taking into consideration his background and all that was happening in his society at the time of the speeches.

\subsection{Biblical Allusions}

In his use of Biblical allusions MLKJ focusses on four aspects: love, nonviolence, equality of men and keeping the faith. These allusions march with the intentions of his messages, focussing on love as an important instrument used to fight for racial justice. He implies Jesus' commands to 'love your neighbours' calling on Americans to show love to man in general without distinguishing whether the man is white, black, yellow or brown. In the Great March on Detroit and in Give Us the Ballot, he quotes Jesus telling his followers to 'love your enemies and bless them that curse you and pray for them that despitefully use you' (Luke 6:27 and Matthew 5: 43-48). In Give Us the Ballot he emphasizes that he is talking about a type of love which will cause one to love the person who does the evil deed while hating the deed that person does. He elaborates on this, specifying that this kind of love is not aesthetic, romantic, or philia but agape- the love of God in the hearts of men. In Beyond Vietnam and Where Do We Go from Here, he reiterates Saint John in 1John 4:7-8 saying, 'let us love one another, for God is love'. He sums up the love of God with reference to Saint Paul's first letter to the Corinthians 13:1-2 where Paul says 'If I speak in tongues of men and angels, but have not love, I am only a resounding gong or a clanging cymbal'. MLKJ says in the Great March on Detroit 'You may have eloquence of speech: but if you have not love, it means nothing'. 
In Give Us the Ballot and the Great March on Detroit he portrays the glaring image of Peter when he uses his sword to cut the ear of a servant of the high Priest, who comes with those that come to arrest Jesus. Jesus picks up the ear and fits it back and tells Peter 'Put your sword back into its place; for all who take the sword will perish by the sword'(Mt 26:52). Even in that situation where he was to be arrested, Jesus showed love. Through these biblical allusions MLKJ shows his followers that nonviolence is for the strong and not for the weak, passive and fearful demonstrator. In I Have a Dream, he persuades the people to continue with peaceful demonstrations and alludes to the image of not 'drinking from the cup of bitterness and hatred' (Jeremiah 2:13) but to love 'bless them that persecute you' (Luke 6: 27). In Beyond Vietnam MLKJ alludes to the story of the Good Samaritan in Luke 10:25-37 of the Holy Bible. In referring to the Good Samaritan he is criticising America's involvement in the war in Vietnam and stands on his position of nonviolence. The story of the Good Samaritan is all about a man who is beaten and abandoned by thieves on the way from Jerusalem to Jericho, and a Samaritan passing by, carries him to an inn and asks that he should be taken care of. Accordingly, America should be the Good Samaritan not only in helping poor countries and fighting against communism but also in a positive revolution of values.

This is a strong argument put by MLKJ why the blacks should not be violent in their quest for equality. He makes his audience understand, the Bible states that God is loving and is interested in all he created and all are the children of God. In I Have a Dream he alludes to Gal 3: 28 where St Paul makes the Christians in Galatia to understand blackmen and whitemen, Jews and Gentiles are all God's children, so there should be justice for all God's children. And in Where Do We Go from Here he calls on the blacks to be dissatisfied until every state capital will be housed by a governor "who will do justly, who will love mercy and who will walk humbly with his God (Micah 6:8). MLKJ alludes to the children of Israel in the Bible when they were being terrorized by their neighbours and were in 'chains of discrimination' (Isaiah 52:2), in 'exile in his own land' in the 'dark and desolate valley' passing through trials and tribulations in the valley of despair (Isaiah 7:19), to present the situation of the blacks in America at the time. He uses the vivid expressions of the oppressed blacks so they can see their own situation in the light of the Israelites in the Bible. He uses images from the Bible like 'lift our nation from the quicksand to a solid rock of brotherhood, 'hewed out of the mountains of despair' and 'every valley shall be exalted...', 'bright day of justice' and 'justice will roll down like waters, and righteousness like a might stream' (Amos 5:24) to give the blacks the hope of the day when there will be equality between the blacks and the whites. Using Isaiah 11:6 in Where Do We Go from Here, he calls on the blacks to be dissatisfied until that day when the lion and the lamb shall lie down together and when they realise that God made all men on the face of the earth (Acts 17:26).

He gives them hope by telling them not to be satisfied but fight nonviolently because even though the Israelites suffered, they finally left Egypt. And even when they crossed the Red Sea they still had problems. He also inspires them with the core of the Christian faith which is the death and resurrection of Jesus Christ. He says 'Good Friday may occupy the throne for a day, but ultimately it must give way to the triumphant beat of the drums of Easter'. The core of the Christian faith is that Jesus died for three days, resurrected and is alive forever. MLKJ's promise to the blacks is that they will succeed if only they do not give in to despair. He also uses the movement of the Israelites from Egypt (Exodus 14) to make them see they are supposed to have faith as he says even though sometimes it is hard, 'but it is always difficult to get out of Egypt, for the Red Sea always stands before you with discouraging dimensions' and even after the Red Sea there is still the move through 'a wilderness with prodigious hilltops of evil and gigantic mountains of opposition.' In Where Do We Go from Here he makes them understand that these oppositions will always be there but they should never give up or despair, instead they should keep moving amid obstacles and amid mountains of opposition. In consolation in We Shall Overcome he encourages the blacks with the wordings of Psalm 121:7-8, where the psalmist says God is keeping watch over His own. In I Have a Dream in telling the people to keep the faith he tells the blacks his dream of a day when life will be better, a day when they will be able to 'hew out of the mountain of despair, a stone of hope.' In the speeches used in this study MLKJ focuses on love, faith and hope, a biblical allusion from I Corinthians 13:13 where St Paul writes to the Corinthians that faith, hope and love should abound in them but they should know love is the greatest.

\subsection{Antithetical Structures}

MLKJ uses antithetical structures to express his disgust for racial discrimination. He uses it to show the vivid pictures of what is and what is supposed to be, or what is and what the blacks hope will be in future. Usually in these expressions he uses the contrast presenting the present as negative, against the positive future. MLKJ makes ample use of the images of light and darkness, the society, physical features, water and heat.The image he gives to the blacks is a movement from one point to the other implying one situation to another. That is why he 
takes a vivid example of the exodus of the Israelites from Egypt to the Promised Land. He presents their long stay in captivity, shame and poverty as against a hope for freedom, dignity and prosperity.

MLKJ makes allusion to light and darkness in his contrasting of the present and the future. He presents the future as day, light and bright and the present as night and dark. In I Have a Dream he presents the Declaration of Independence, not only as 'a joyous daybreak to end the night of human captivity' but also as a 'great beacon light of hope to millions of Negro slaves who had been seared in the flames of withering injustice'. In Beyond Vietnam, he expresses his disappointment with the involvement of America in the Vietnam war, using light and darkness. According to MLKJ 'we are deeply in need of a new way beyond the darkness that seems so close around us'. And calls on the Negroes to be dissatisfied until the 'dark yesterdays of segregated schools' will be transformed into 'bright tomorrows of quality integrated education'. He uses the image of light and darkness in giving a vivid picture of racial injustice in every sphere of life. In I Have a Dream he talks of the 'dark and desolate valley of segregation' as opposed to 'the sunlit path of racial justice'. He looks at equality, justice, social integration as 'light' and inequality, injustice, social and educational segregation as darkness and consoles the blacks that the "whirlwinds of revolt will continue to shake the foundations of our nation until the bright day of justice emerges'. These image of light: bright day, sunlit path, bright tomorrows, joyous daybreak, great beacon light of hope all carry adjectives that are positive and promise a bright future. Meanwhile 'dark and desolate valley, long night, darkness and all pertain to the past and present days of sufferings, sorrow and pain.

Another image used to describe the contrast between the present and the future situations of the blacks is that of physical features. In the Great March on Detroit he refers to the present time as 'the quicksands of racial injustice' and the time hoped for as 'solid rock of racial justice'. In telling the people to keep on hoping he promises that he will 'carve a tunnel of hope through the mountain of despair'. This promise gives hope to the people because in the use of glaring images with vivid adjectives the people are convinced he will be there to fight on with them. He uses the voice of prophet Isaiah 40:4 when he is addressing the people to prepare the way for the Lord's coming, emphasizing on a bright future worth fighting for. He tells his audience 'I have a dream that one day every valley shall be exalted, every hill and mountain shall be made low the rough places will be made plain and crooked places will be made straight'. For the people to imagine an exalted valley, a low hill and mountain, plain and straight places, means they have every reason not to give up. He presents to the Negroes, their situation, living on a 'lonely island of poverty' as against the 'vast ocean of material prosperity'. The contrasting adjectives raise the awareness of the Negroes to see their plight in the image of physical features. He promises them that the heat of oppression will be transformed into 'an oasis of freedom and justice, and a 'Mountain of despair' will be transformed into a 'stone of hope'

In the Great March on Detroit, I Have a Dream and Beyond Vietnam, MLKJ contrasts the present with the future using the disgusting and enjoyable sounds of music in the antithetical structure 'the transformation from jangling discords of our nation to beautiful symphony of brotherhood'. 'Jangling discord' insinuate harsh sounds of metal objects that are in disorder represent the present state of suffering, anger and strive, while the 'beautiful symphony', sound of music that is well-arranged and harmonised, representing a beautiful life with no discrimination. Another image of music comes the Great March on Detroit and Beyond Vietnam when he says 'now is the time to transform this pending national elegy into a creative psalm of brotherhood'. The elegy, which is a song of sorrow sang especially at a funeral, represents the present sorrowful state of the blacks while the psalms that is a sacred song of worship used especially in the Old Testament, is the hope of a promising future.

MLKJ also makes use of the image of heat. In I Have a Dream, the Negroes are 'searing in the flames of withering injustice, and sweltering with the heat of injustice and oppression as against the oasis of freedom. The summer of the Negro's legitimate discontent is sweltering but hoping for an invigorating autumn of freedom and equality. Heat here represents discomfort as against the hope of a more lively and healthy future.

\subsection{Triad}

Martin Luther King makes enormous use of the triad as a technique to powerfully get to his audience and get them to understand, feel and react to his message. The use of three has a significant role in the speeches of MLKJ, creating a musical impact that leaves the words ringing in the minds of his listeners. He uses it in words, phrases and sentences.

In Give Us the Ballot MLKJ makes ample use of mostly the triad of words and in particular, adjectives to qualify nouns. He specifies the language by the Supreme Court to free blacks as 'simple, eloquent and unequivocal' implying that the language used is clear, and succinctly passes across the message but the impact is not felt by the people. To refer to the whites in the South who are disseminating false ideas he says, they are 'a close-minded, 
reactionary and recalcitrant' group but calls on the blacks to struggle for a 'strong, moral and courageous' leadership. This leadership should not be violent but should go along with love because even in the very South, there are some whites who are for the course of the blacks but are silent because of the fear of 'social, political and economic' reprisals. He calls on the blacks as usual to be nonviolent in their fight because "we must never struggle with 'falsehood, hate or malice'.

In Beyond Vietnam, he describes the blacks in the ghettos of the North as 'desperate, rejected and angry' young men, obviously ready to be violent. The use of these adjectives and nouns give vivid images, raising the awareness of the blacks and portraying their desperate situation. But he focusses on nonviolence in the fight for their rights even though the 'blacks must fight today and not tomorrow' because they will be left 'bare, naked and dejected' if they procrastinate. In I Have a Dream he specifies that these rights include 'life, liberty and the pursuit of happiness.

MLKJ uses a series of triad to educate the blacks and encourages them to continue with the struggle. In Beyond Vietnam he sees war as having distorted the poverty alleviation plan. He explains that the involvement of the war has destroyed 'experiments, hopes and new beginnings' because it continues to draw 'men and skills and money'. He presents America as Vietnamese's enemy because they put 'women, children and the aged' in concentration camps and thousands of children wander homeless, without clothes, running in packs on streets like animals. MLKJ's cry is that this is against the 'race or nation or creed' of America to support governments that were 'corrupt, inept and without popular support'. He reminds the nation that the physically handicapped and psychologically deranged men sent home from battlefields cannot be reconciled with the 'wisdom, justice and love' that the American nation is supposed to show. He advises that the nation should instead fight 'poverty, insecurity and injustice' that breed communism and declare hostility to 'poverty, racism and militarism'. In this nonviolent campaign, he cries out that the giant triple that will be incapable of being conquered is 'racism, materialism and militarism'. According to MLKJ if no action is taken they shall surely be dragged down the 'long, dark and shameful' corridors of the time reserved for those who possess 'power without compassion, might without morality, and strength without sight'.

In the Great March on Detroit, MLKJ's uses triad phrases to raise the awareness of the and how unjust it is to refuse them their rights. He says it is "not only sociologically untenable, it is not only politically unsound, it is morally wrong and sinful' and he goes on to explain that this can be seen 'in the area of employment discrimination, in the area of housing discrimination, and in the area of de facto segregation in the public schools'. Later on in I Have a Dream he hopes for a day when all these will be bygones and there will be love, when all God's children 'black men and white men, Jews and gentiles, Protestants and Catholics' will be able to live together. He carries this on to a more radical triad in Where Do We Go from Here, when he calls on the Negroes to be dissatisfied until every state capital will be housed by a governor 'who will do justly, who will love mercy and who will walk humbly with his God.

In Beyond Vietnam, MLKJ answers to the accusation of being a civil rights fighter but is against the Vietnam war which was considered a fight for human rights. He says he cannot be silent 'for the sake of those boys, for the sake of this government, for the sake of the hundreds of thousands trembling under our violence'. He expatiates on this by giving the true meaning and value of compassion and nonviolence when he quips that 'it helps us to see the enemy's point of view, to hear his questions, to know his assessment of ourselves'.

MLKJ also uses triads that are declaratives. In the the Great March on Detroit he informs the government 'We want all our rights, we want them here, and we want them now', because according to him time is not on their side. He goes on in Beyond Vietnam to declare 'Surely we must understand their feelings, even if we do not condone their actions. Surely we must see that the men we support pressed them to their violence. Surely we must see that our own computerized plans of destruction simply dwarf their greatest acts'. And in Give Us the Ballot he encourages the blacks with this triad, 'Keep going today. Keep moving amid obstacles. Keep moving amid mountains of oppression'. With these declaratives he is passing on information and using the triad makes his messages rhythmic, emphatic and more memorable.

\section{Conclusion}

This study has shown that there is a relationship between language and the society, and the different events in the society bring about different language registers. The sociopolitical situation therefore at the time of MLKJ brought about a particular structural pattern in his speeches. This pattern and his use of language had and still has a powerful effect on his listeners and readers. This study has permeated the different speeches and brought out the biblical references, antithetical structures and the triad as some of the secrets behind the enticing speeches made by MLKJ. 


\section{References}

Ayeomoni, M. O. (2001). Style in Nigerian Political Speeches in IFE Studies in English Language Journal. Dept of English, OAU: Ile-Ife.

Craigie, A. W. (2013). Do you use the Rhetorical 'Rule of Three? Retrieved from www.craigielawfirm.com

Crystal, D. (1998). Language Play. London: Penguin.

Crystal, D., \& Davy, D. (1969). Investigating English Style. London: Macmillan Press.

Dlugan, A, (2012). Six Minutes speaking and Presentation Skills Speech Analysis: I have a Dream-Martin Luther King Jr. Retrieved from Six minutes.dlugan.com

Good News Bible. (1994). Australia: The Bible Society in Australia INC.

Halliday, M. A. K. (2003). On the "architecture" of human language. In J. Webster (Ed.), On Language and Linguistics. The Collected Works of M. A. K. Halliday (vol. 3, pp. 1-29). London: Coninuum.

Halliday, M. A. K., \& Hasan R. (1985). Cohesion in English. London: Longman.

Kerry, S. (2011). Analysis of literary Devices in I have a dream by Dr. Martin Luther. Retrieved from Samwiterson.blogspot.com

Khattak, M. I. et al. (2012). The Role of Stylistics in Interpreting Literature. City University Research Journal, 2(1), 97-102.

Lull, D. J. (2011). Remembering Martin Luther king Jr. King's Vision of Justice: Rooted in the Bible. Retrieved from www.ncccusa.org

Sarah, L. H. (2012). I have a dream speech: Martin Luther King Jr: the anatomy of an inspiring speaker. Retrieved from www.gingerpublicspeaking.com

Schwertly, S. (2013). The importance of the Number Three in Presentations. Retrieved from https://alexrister1.wordpress.com

Sinclair, J., \& Coulthard, R. M. (1978). Towards an Analysis of Discourse: The English used by Teachers and Pupils. Oxford: Oxford University Press.

Stanford Encyclopedia of Philosophy. (2010). Aristotle's Rhetoric. Retrieved from Plato.stanford.edu

Taylor, T. J. (1980). Linguistic Theory and Structuralist Linguistics. Oxford: Pergamon.

Widdowson, H. G. (1975). Stylistics and the Teaching of Literature. London: Longman.

Wikipedia. Modes of Persuasion. Retrieved from https://en.wikipedia.org

Wikipedia. Sermons and Speeches of Martin Luther King, Jr. Retrieved from https://en.wikipedia.org

Yeibo, E. (2011). Patterns of Lexical Choices and Stylistic Function in J.P. Clark- Bekederemo's Poetry. International Journal of English Linguistics, 1(1), 136-149. http://dx.doi.org/10.5539/ijel.v1n1p137

\section{Copyrights}

Copyright for this article is retained by the author(s), with first publication rights granted to the journal.

This is an open-access article distributed under the terms and conditions of the Creative Commons Attribution license (http://creativecommons.org/licenses/by/3.0/). 